\title{
Socio-Historical Study on the Rise and Growth of Pentecostal Churches
}

\author{
Liza L. Chua \\ Dean, College of Teacher Education, University of Cebu \\ Sanciangko Street, Cebu City, Philippines
}

Jhon Kevin A. Mirafuentes (Corresponding author)

Master Student, Department of Religious Study and Organization Management

Aletheia University

32 Chen-li Street, Tamsui District, New Taipei City 25103, Taiwan

E-mail: reycamion21@gmail.com,aljhonnas_88@yahoo.com.ph

Jonathan O. Etcuban

Campus Research Director, University of Cebu

Sanciangko Street, Cebu City, Philippines

Received: April 18, 2017 Accepted: June 21, 2017 Published: June 30, 2017

doi:10.5296/jad.v3i2.11081 URL: https://doi.org/10.5296/jad.v3i2.11081

\begin{abstract}
Christianity is one of the greatest institutions ever founded in the human race. It is a divine institution that was founded by Jesus Christ to carry out His mission in the world laying the foundation of love and salvation as a free gift to everyone. The Christian church history insulated into different periods that are separated by great events. The study focused on the historical beginnings, the rise and growth of Pentecostal Churches and contributing factors which led to its establishments, spread and expansion. It was mainly anchored on Mc Gavran's theory on Church growth and Christian mission which discussed about the three main varieties of church growth namely: biological, transfer, and conversion growths. It utilized Qualitative and Quantitative procedures using Historical Approach. The study found out that upon the birth of Pentecostal Churches, they hold distinctive teachings yet they have some slight differences in the structure of leadership. Though they have almost the same practices of Christianity, what matters most is they follow the teachings of the Bible in a different dynamic ways.
\end{abstract}

Keywords: Christianity, Pentecostalism, Mc Garvran's theory, Hamilton's Lessons for Churches, Mike Bishop's Church growth paradigm 


\section{Introduction}

Christianity is one of the greatest institutions ever founded in the human race. It is a divine institution that was founded by Jesus Christ to carry out His mission in the world laying the foundation of His love and salvation offered as a free gift to everyone. His humble birth marked the greatest miracle of history. The Christian church history insulated into different periods, which are separated by great events. In order to understand the different significant events in the present, the study claims that that there is a need to know the past, especially how the church has begun, flourished, and influenced.

The Christian Church history experienced a long tide of events from its growth as a young church beginning in A.D. 33 up to the present. It is interesting to note how Christianity survived amidst all the surging events of time. In the course of history, the church experienced movements, religious activities and developments. One popular development is where this study is heading to and that is about the Christian movements and revivals in our times. A great Christian church revival in modern times was started most remarkably by Edwards called the Great Awakening that took place in New England from 1734-1744, and another was by Finney, a great American revivalist in 1792-1875 and by Moody in the last quarter of the $19^{\text {th }}$ century (Kuiper, 1951). In recent times, Christianity in the $20^{\text {th }}$ century has witnessed the emergence of the Pentecostal Movement that swift throughout the whole world. Pentecostals are Christians who are members of the Pentecostal denomination whose main characteristic is the rediscovery, and a new experience of the supernatural with a powerful and energizing ministry of the Holy Spirit. Historians often trace the origins of Pentecostalism in the American context to a revival that began at Charles Parham's Bethel Bible School in Topeka, Kansas on January 1, 1901.

Since this historical event of revival has prospered in the present, the researchers believed that the rise and growth of religious events, specifically Pentecostal Church, must be included in teaching History and Sociology for College students in order for them to understand their beginnings and development. It is their desire to guide students to understand how different denominations emerged particularly in the Philippines. Moreover, knowing the factors that contributed to the churches' rise and growth, believes that finding out the church members' personal inclinations, interests and desires in seeking their fulfilment in the physical, social, moral, economic and spiritual areas of their lives being connected to a particular congregation, may understand its existence, practices and influences.

Therefore, the study traces the socio-historical background of the rise and growth of the three pioneering Pentecostal Churches in Cebu City from 1955 to the present. The study utilized Qualitative and Quantitative procedures using Historical Approach. Based on findings, the researchers will produce a learning manual in Sociology to better understand the religious influence to the lives of the students.

\section{Historical Framework}

Christian church history developed in a wide variety of events, movements, religious activities and developments thru the ages. The Church is said to be able to adjust the ever historical and cultural changing situations without modifying its message.

Wacker (1988) pointed out that if the governance of history was simultaneously divine and 
human, so too, the direction of history was simultaneously linear and cyclical. This to say that history was linear in so far as God exercised control; cyclical in so far as God permitted humans to use and misuse freedom. Humans took a disturbingly repetitive form. Overtime, vibrant churches and respectable churches would become almost by definition, spiritually cold and lifeless. Sooner or later a small body of saints humble and repentant, would break away to set up their own fellowship.

Linder (1977) stated that each period of Christian history has included its own share of special events and difficulties, its distinctive and unique changes. Another most noticeable feature of Christian church has been the amazing ability of the faith periodically to reform and renew itself. Historians are often struck by the resilience of Christianity and its seemingly inexhaustible capacity to revive after periods of stagnation or decay.

Throughout the history of Christianity, that pattern has been repeated countless times. Thus, once a church has a spiritual deadness, a spiritual revival usually happens. Revivalism has been the essence of American Christianity. Bainton (1977) said that "Coldness and corruption in the Orthodox churches provoked many Christians a desire for greater spiritual warmth and reality". Moyer (1951) defined it as periods of religious awakening when sinners are converted in phenomenal numbers. Revival is essentially an awakening to the new life of the Christians. The result of worldwide revivalism however became the object of widespread opposition. Those who desired to retain their charismatic religious way of life found it increasingly difficult to do within the institutional framework of Protestantism. As a result, many who hold such views withdrew from their churches to form a new and distinct Pentecostal groups (Blackett, 2000). Thus, the $20^{\text {th }}$ century witnessed the emergence of Pentecostal movement across the globe. Interestingly, explosive increase of Pentecostal movements resulted to the emergence of many newly formed churches. In the most recent demographics according to Anderson as cited by Cortez (2014), there were 631 million Pentecostals in 2014 comprising nearly one fourth of all Christians. There were only 63 million Pentecostals in 1970 and the number is expected to reach 800 million by the year 2025 (Cortez, 2014).

Blackett (2000) explained that with its focus on experiential Christianity, many are drawn to it. Ed Stetzer (2014) said that there parts of the globe where the greatest church growth is happening through the Pentecostal movement. From a statistical perspective, Pentecostals tend to be less nominal than other believers. The reason is often obvious-the Baptism of the Holy Spirit. In almost all Pentecostalism, speaking in tongues follows the Holy Spirit's baptism. When you believe you are speaking in another language, that belief reshapes the way you think about faith. When you appreciate what you have as much as Pentecostals do, you are not satisfied to experience it yourself. You think others should have the same opportunity to partake of the movement of the Spirit of God. He continued saying, when I met with Pentecostal leaders, they are strategizing about where to plant a church. Never mind there are already six churches in a 10-block community. To them, there is not a Spirit-filled church in that community until they plant one. So they are often avid planters, not just in their own area, but also around the world. The study is anchored on the Mc Gavran (1972) on Church growth and Christian mission which emphasized three main varieties of church growth namely: biological, transfer and conversion growths. 


\section{MInstitute ${ }^{\text {Macrothink }}$}

Firstly, the Biological church growth is those that are born in a family embracing the same faith with that of their parents and eventually become full members in the same church adding to their numerical growth. Although this is a necessary type of growth, but it will never win the world to Christ, for while Christians are begetting their hundreds, non-Christians will beget their thousands. Secondly, the Transfer church growth which is like having ten dollars in your right pocket, and you took it out and put it in your left pocket. Your left pocket is now ten dollar richer but the right pocket is ten dollars poorer and you yourself are no wealthier than before. Much "growth of the church" in the cities is transfer growth. City churches grow but country congregations die. However, important that Christians who moved should join Christian churches where they go, it is obvious that such transfer growth will never disciple the nations. The third is Conversion church growth which is the extension of God's grace to more and more people. In other words, this is when they truly accepted Christ in their life as their only Savior and Lord. With their acceptance of Christ, they also testify with others about their faith converting others to believe in God. Moreover, Mc Gavran (1972) explained that it was why when Silas and Timothy returned from Macedonia, they found Apostle Paul arguing in the synagogue every Sabbath and persuading Jews and Greeks to become disciples of Christ, testifying to them in every need that the Christ was Jesus and none other (Acts 18:4-5). Paul was working for conversion growth. Biological and transfer growth come through shepherding. Conversion growth has to do primarily with extending God's grace to those who are not yet disciples.

Another theory that supported the study is Rev. Adam J. Hamilton's (2000) critical elements to any growing church. These are (a) Relevant, interesting, Inspiring and Compelling Sermons; (b) Moving and Dynamic Music; (c) Warm, Well-Maintained, Updated and Inviting Facilities; (d) Bright, Cheery, Quality and Safe Nurseries; (e) Ministries that Meet the Needs of Unchurched People; (f) Friendly, Excited and Energized Laity; (g) Regular, High Quality and Inviting Marketing/Advertising; (h) Excellent and Immediate Follow-up with First-time Visitors; (i) A Compelling, Biblical Vision, Purpose or Mission; and (j) Pastors, Staff and Lay Leadership that are Passionate about their Faith.

Successful churches are like successful restaurants, and unfortunately, struggling church is like struggling restaurants. Hamilton (2000) asked us to read through the list again - which restaurant that best describes your church.

There are other theories and assumptions on church growth to further understand the study. In an interview made by Adams and Tryggested (2002) with Martin, the latter mentioned some important 'tips' on how their church in North Country grew. The interviewee summarized his answers as follows: (a) members are challenged to the standard of overcoming their own fears, frustration or agenda to become effective witness to the world for Christ; (b) they have groups that meet weekly and ministry will meet two to four families per week to hear their personal encounter with the Lord and how they ask God for help; (c) Sunday is always the worship service where in singing, prayer and participation in the Lord's supper and a greater emphasis on the Word of God are showed; (d) reaching to minority populations in their area, all visitors are given follow-up phone call by their particular peer ministry leader; and (e) members who were absent are also checked with the concern whether they get sick, discouraged etc. Martin also gave an advice for churches who want to grow. He said, 
"Find out what God is doing in your ministry. Nothing God gives to you is a reason you're not growing. I've heard people say, that church has many people to grow. Make the older people a reason for growth. Target older people. You have the resources to reach out to them. Make a prayer priority...shepherds, make it a goal to spend time with one of the families each week and find out what is God doing in their lives and what you can be praying for them. Congregations need to keep traditions in perspective, and we need to distinguish the essential pattern seen in the New Testament from our 'church of Christ' traditions that say how to do everything. Our positions on these things must come convincingly from the Word. The next generations will not accept them because we have believed them, but because they are grounded on the Scriptures".

Bishop (2002) has presented his basic assumption that he called 'Church growth paradigm: (a) A simple vision which brings the Gospel of salvation in Jesus to the entire world by any means necessary; (b) Ethnic groups, generational groups, special needs, etc. are identified, studied, targeted and advanced upon with his Gospel in hopes that they will be assimilated into the kingdom and church; and (c) Massive amounts of funding, personnel, strategy, planning and leadership are necessary to pull off this enormous undertaking.

He considered the Church as a subversive community. He gave a different meaning to the word subversive which comes from Latin--subvertere, literally means, 'to turn from beneath'. He explained that Subversive Community's mission is not bringing the Kingdom of God from without. It is to release the Kingdom of God from within. Subversives live and do their work 'undercover' where the world lives and breathes. The principal goal of the Community is to train other subversives, which is really what the Great Commission was all about. He referred to Peterson's "the Contemplative Pastor" and Andrew Jones tag line: "One who tell stories and throw parties". Combining all these, he came up with what he called, the "Three-P's of Church Planting" - Prayer, Parables, and Parties. He said that Prayer means praying for what God has created us to be a community. The second is Parables which mean the Subversive Community can utilize parables in many different ways. Jesus utilized parables like ticking time bombs of truth implanted in His hearer's minds. Parable is considered to use when people invite the Holy Spirit to tell God's story through life. Finally, the Parties which means the community that call for fellowships. The Community can invite friends to come because they believe that the church is the people. Then, upon hearing to God's Words are the real works of the world.

Sharma (2001) wrote about the Pentecostal movement in Nepal. It was started by Pentecostal missionaries in Rupaidiah where were one of the earliest mission centers and some of the American Assembly of God missionaries worked in this place. Barbanas Rai with his wife came to Rupaidiah as missionaries there. In this humble beginning, God rewarded the work of the pioneers. Several people became Christians. Barnabas Rai emphasized the Pentecostal experience from the beginning of his ministry. Without much detailed teaching, people received the baptism of the Holy Spirit, with speaking in tongues. Then Rai and his family moved to Nepalganj in Nepal in 1951 after the declaration of democracy. The Lal Bahadur Shrestha family became Christians in 1954. There were other converts in Nepalganj area.

Another study is Andrew Rogers' Being Built Together project found 240 black majority 
churches in Southwark, south London, the greatest concentration of African Christianity in the world outside of Africa it is believed. Here Rogers (2016) looks at how this relates to the broader picture of church growth and decline in the UK, finding that urban religious landscapes have changed dramatically over recent decades. This has important implications for public policy, including planning policy and practice. The Being Built Together project investigated the number, places and priorities of new black majority churches (BMCs) in the London Borough of Southwark over 2011-13. The particular interest was in BMCs formed independently of the historic denominations since the 1950s. The catalyst for this research was the rapid growth of BMCs in the borough over recent decades and the consequent shortage of suitable places of worship. Southwark BMCs were predominantly African majority, especially West African, and although not mono-cultural, there were very few whites. Most (but not all) identified as 'Pentecostal', featuring long services characterised by exuberant and often loud worship. Many of the BMCs were led by first generation migrant pastors, and an international mentality was evident in pastor interviews and church names. In conclusion, it is recognized that BMC numbers and growth largely occur within $3 \%$ of the population in England and Wales or $11 \%$ of the population in Greater London. Therefore claims about BMC church growth in the face of overall decline need to be suitably modest. Nevertheless, there is little evidence that BMCs are slowing in their growth, and the concentrations of BMCs in British urban centres may well have an impact beyond their numbers in terms of stimulating the religious marketplace. Furthermore, the Southwark case points to a rather more nuanced picture of church growth and decline in the UK, where urban religious landscapes have changed dramatically over recent decades due to rapid BMC growth. Understanding the growth and priorities of BMCs is also important for public policy in a number of domains, including planning policy and practice (Rogers, 2016).

Another related study is the brief history of the Pentecostal Assemblies of Canada (author's name unacknowledged). In the early 1990's, the Canadian Pentecostal leaders were from religious family deep-rooted in the Holiness movements, and one of those was Robert McAlister. In 1906, McAlister heard about the notable expression of God's Spirit; thus, he travelled to Los Angeles. On December 11, he was baptized. Then, that began the birth of the initial physical evidence of the Pentecostal experience by sharing his experiences with the Spirit. Likewise, a Methodist lay preacher and manager of men's shop, Mr. Charles Baker, had recently found out that his wife had a cancer. He brought her to Mr. McAlister and he helped her pray until she was healed by God's help. Recently, the Canadian Pentecostal believers have been increasing.

Christians believe that by the power of the God's Holy Spirit, which was received during the baptism, is the distinctive feature that also attested by the manifestation of 'speaking in tongues,' as recorded in the Book of Acts. While, the Pentecostal believe that the major emphasis of this revival is preaching of salvation through repentance from sin and faith in the Savior, Jesus Christ. Thus, the number of congregation and Pentecostal members continued to increase. This simply means that God's guidance and grace, through His Holy Spirit is evident through the years. Though, there were concerns and challenges they face, Pentecostal people, however, continue to spread their beliefs. But sooner, the Pentecostal leaders became aware of the organization's needs. Therefore, coordination and participation were shown by 


\section{MInstitute ${ }^{\text {Mink }}$}

both leaders and members to provide a basis for fellowship among ministries and churches in the interest of the doctrinal agreement; for the endorsement and support of missionaries, and for the promotion of the effectual operation of the Holy Spirit in Canada and across the World. By 1917, in order to promote unity, the Church has extended their fellowship in the Eastern Canada, there, the Church has filed an agreement between the Church and the Canadian Movement.

Another account of the Elim Pentecostal Church which was composed of the Jeffreys brothers: Stephen, William and George. They were brought up in the mining area along with most of their village fellows worked in the mines. They were ignited by the revival of those days and as a result, they offered themselves to God and God blessed them. Opportunities came along and there were many who followed their ministry. It was George, however, who became overwhelmed with the need of not only evangelizing the people, but also amalgamating them in follow-up, by providing them with places where they could regularly gather and form themselves into churches.

In 1914, when the beginning of the first World War, Christian Convention was held in Belfast, Northern Ireland. The organizer agreed young George Jeffreys to attend. At the convention, he met Alan Kerr and George Allen that eventually they decided to invite him to their own town to conduct a movement that was arranged in 1915. God singularly blessed this effort and Elim was born. The Elim movement has roots that reach back to a visitation of the Holy Spirit of God, which can only be described as a revival from heaven.

Another study is the Catholic Charismatic Renewal. While some individual Catholics had been touched by the Pentecostal movement and had been baptized in the Spirit prior to 1967, the formation of a prayer group among faculty members and students at Duquesne University, Pittsburgh, in February 1967 is generally looked upon as the beginning of the charismatic renewal in the Catholic Church. There are several reasons for seeing it as providential that this beginning took place after that the Second Vatican Council, which concluded its final session on December 1, 1965. Indeed, it seems unlikely that any form of Pentecostalism among Catholics would have been accepted by the bishops and the pope if it had not been for some important decisions that they themselves had made at the council. The first of this decision was the Catholic Church should become a full and active participant in the ecumenical movement. Another decision was opened the way to acceptance of a charismatic renewal in the Catholic Church and that was the recognition of the vital importance of the charismatic gifts in the life of the church. A third element in the teaching of Vatican II that contributed to the acceptance of the charismatic renewal in the Catholic church was its insistence that the call to holiness and to active sharing in the building up of the body of Christ is universal, embracing all of the faithful as well as clergy and those with religious vows. If it had not been for this new emphasis given by the council to the role of the laity in the life of the church it is doubtful that the priest and bishops would have been so open to a movement of spiritual renewal whose origin, growth, and leadership owe so much more to the initiative of lay Catholics than to that of the clergy.

The beginnings of the Catholic Charismatic Renewal in the United States were started by Ralph Keifer and Patrick Bourgeois. They were young lay instructors in the department of theology at Duquesne University, a Catholic institution under the direction of the Holy Ghost 
Fathers. Their interest in the Pentecostal movement was stimulated by the reading of two books: David Wilkerson's the Cross and the Switchblade (c.1963), and John Sherrill's They Speak With Other Tongues (1964). Desirous to experience for themselves the spiritual awakening that Wilkerson's and Sherrill described as the effect of being baptized in the Spirit, and having learned of the existence of a Pentecostal - type prayer group in the Pittsburgh area, they sought and received an invitation to attend the meetings of this group, which were held in the home of a Presbyterian woman. It is significant that it was such a prayer group made up of the people from the mainline Protestant churches, which provided the bridge between Catholics and Pentecostals, as it would undoubtedly never have occurred to Keifer and his friends to attend services in a Pentecostal church. At the second meeting in which they took part, they asked for prayer that they might receive the baptism in the Spirit in which they had the typical Pentecostal experience, including the gift of tongues. In the following weeks they shared their discovery with close friends and prayed with them for the baptism in the Spirit. In mid-February 1967 they decided to spend a weekend in prayer together with a group of about thirty students who had also reflected on the first four chapters of Acts and sought the will of God for their lives. Thus, the first Catholic Charismatic prayer group manifesting the gifts and fruits of the Spirit that characterized the Pentecostal movement came into existence.

As it began in the university campus, the movement soon found adherents at two other universities of Notre Dame and Michigan State. Among the outstanding events in the history of the Catholic Charismatic Renewal in the United States were the annual conferences held in the University of Notre Dame campus. An index of the growth of the charismatic renewal among the American Catholics is provided by the number of adherents who have taken part in the annual conferences at University of Notre Dame. The year 1972 saw the spread of the renewal in Ireland, France, Germany, India, and New Guinea, among other places (Burgess, McGee, \& Alexander, 1988).

A similar study on the rise and growth of Christian churches in the Philippines was made by A. Leonard Tuggy and Ralph Toliver in 1972. The Assemblies of God are the oldest and largest Pentecostal denomination in the Philippines, with a history growth pattern quite representative of Pentecostalism here at large. The first Assembly of God missionaries, Mr. and Mrs. Caudle arrived in 1926 but were unable to continue because of health problems. So the work actually began through a Filipino missionary, Cris Carsulao who had been saved and trained in a Pentecostal Bible Institute in the United States and had returned to his home province of Antique in 1930. Rosendo Alcantara, the General Secretary of the Assemblies of God in the Philippines, also found Christ through the Pentecostal ministry in the United States and returned here to begin the Pentecostal work in the Ilocos area. American missionaries arrived later and the movement grew.

After the war, the Assemblies of God continued rather slow plodding growth until about 1953. Then a new pattern appeared, "The Philippine Pentecost" is the way some leaders refer to the period between 1953 and 1955. Definitely, unusual power was experienced in the movement as a whole. The catalytic event seems to have been that the evangelist Lester Sumrall was able to deliver Clarita Villanueva, a seventeen-year-old inmate of the Manila City Jail, from demon oppression. This was immediately followed by a month of nightly meeting in Roxas Park. Bethel Temple in downtown Manila was then under construction and was soon 
completed. With the striking motto, "Christ is the Answer" emblazoned on its side, this large building became the rallying for the Assemblies of God nationwide advance.

Internationally, the Assemblies of God is the largest grouping of denominations originating from Pentecostalism with roughly 65 million members worldwide. The Assemblies of God was founded just over a century ago, in April 1914. Interestingly, there were no Pentecostals in 1900, yet today Christians with both the Pentecostal and Charismatic Movements make up about $25 \%$ of the world Christian population. The Assemblies of God's four core doctrines include: salvation, divine healing, baptism in the Spirit and the second coming of Christ (Caldwell, 2014).

But this was not the only Pentecostal denomination experiencing special blessing during this period in the Philippines. Oral Roberts and T.L. Osborne, well-known American evangelist, held special campaigns here. Meanwhile, the Philippine Medical Association charged evangelist Erickson with practicing medicine without a license. When this case was thrown out of court, it could only increase the publicity of the Pentecostals. Subsequently their churches began to spring up all over the country: (a) Leonard Tuggy and Ralph Toliver listed some factors that promote growth in the Philippine churches; (b) a nationwide strategy of evangelism-this allows these churches to be very flexible. If they are not growing in one region, the concentrate on another that is more responsive currently. So, all these Churches were able to take advantage of Mindanao's responsiveness during 1950's; (c) a strong emphasis on evangelism and church planting. Too often we search for subtle sociological reasons for growth and overlook the fact that some groups plan to grow, and exert every effort to do so, while others do not. Many churches hold branch Sunday Schools. But not all expect these to develop into new churches like the Pentecostal churches do; (d) a close tie between churches and institutional work, especially in the Bible schools. The Bible school program is geared to denomination's plan for expansion. Medical work has strong evangelistic overtones. Literature ministries are aimed toward church growth; (e) a multilevel ministry for the churches. This includes the strategic use of Women Ministers (sometimes called "Bible Women"), without whom many small congregations would not be cared for; (f) a low ministry-to-communicant-member ration. This is especially true among the Pentecostalists and the Seventh-Day Adventists, but also characterizes the other denominations in the areas where they are growing rapidly. This simply means that growth definitely is not tied to the physical presence of a missionary, and that this is not "forced growth" but "spontaneous growth"; and (g) an emphasis on both centrifugal and centripetal growth. Growth both radiates from the center and moves into the center. So we find these fast-growing denominations both building strong center churches and emphasizing rural evangelism.

The researchers visited the libraries of the University of San Carlos, Immanuel Bible College, Cebu City Foursquare Gospel Church and the Philippine Council Evangelical of Churches in quest for related studies. Unfortunately, their inquiries about similar studies proved the churches' lack of records of their own church histories. Only a thin clippings made by Varela (1998) from the Philippine Council of Evangelical Churches titled "A History of Biblical account of different Christian churches in the city of Cebu" was available.

However, similar religious studies were also consulted like Anselmo Tomolin Nermal's "The 


\section{Ml Macrothink}

Growth and Development of the Seventh Day Adventist Church in Northern Mindanao 1973-1983. It yielded a similar emphasis on the origins and growth of their church, which is one of the data sought by the researcher in her study of the Pentecostal churches. They are also similar in terms of methodology, which calls for a historical study where documents and other important data were collected for analysis and evaluation. Pradham (1994) mentioned in the study titled "The Protestant Chinese and their Contribution to the Socio-Economic and Cultural Development of Cebu City, 1916-1988" has its similarities found in this current research problem about its search for the historical background, growth, and contributions to society. Inversely, Labajo (2002) also conducted oral interviews in the historical study titled "A Historical Survey of Reformative and Dissident Religious Movements in Cebu 1900-1990" to find out the historical beginnings of the churches in Cebu.

\section{Design and Methodology}

This is a Qualitative study using Historical Approach. The data were gathered by means of qualitative and quantitative data collection procedures. The qualitative method used the interview guide, oral interviews and participant observation. Interviewing current church leaders, retired pastors, other important informants and collecting written sources and pictures were utilized in getting both primary and secondary sources considered very helpful in tracing its church beginnings and other important features. Church members on the other hand were given questionnaires to get important data on their current congregational programs. Likewise the researcher visited the research sites which are the places of worship and observed and participated in Sunday church services for six months until the data collection was finally completed.

The researchers chose three pioneering Pentecostal churches in Cebu City, namely, the Cebu City Foursquare Gospel Church, The Faith Tabernacle and the Immanuel Fellowship: (a) the Church of the Foursquare Gospel; (b) the Faith Tabernacle; and (c)the Immanuel Fellowship.

The respondents of the study were the church pastors, retired pastors, other key informants, and the church members of the three pioneering Pentecostal churches. Each church pastor was given a six-page questionnaire and separate oral interviews which were all recorded in a tape recorder. The informants were retired pastors and other connected church leaders who served as good sources of information about the church historical beginnings and the church leadership structures. The church members were also given separate open and close questionnaires. Since the three churches have different population, the researchers employed the stratified proportional random sampling based on the Sloven's formula for computing the sample size:

$$
\mathrm{a}=\frac{N}{1+\mathrm{Ne}}
$$

where:

$$
\begin{aligned}
& \mathrm{n}=\text { sample size } \\
& \mathrm{N}=\text { population (household) } \\
& \mathrm{e}=\text { level of significance }
\end{aligned}
$$




\section{Macrothink}

Table 1. Distribution of respondents from the three churches

\begin{tabular}{llll}
\hline Churches & Population & \% in Population & Number of Samples \\
\hline 1.Foursquare Church & 74 & $32.599 \%$ & 47 \\
2.Faith Tabernacle & 86 & $37.885 \%$ & 55 \\
3.Immanuel Fellowship & 67 & $29.515 \%$ & 43 \\
\hline $\boldsymbol{\Sigma}$ & $\mathbf{2 2 7}$ & $\mathbf{9 9 . 9 9 9 \%}$ & $\mathbf{1 4 5}$ \\
\hline
\end{tabular}

The characteristic of the population is such that the proportions of the subgroups are unequal. The researcher wishes to maintain this characteristic in the sample. The proportion of each stratum is computed by dividing the number of members in each stratum by the total population. The multi-stage sampling was used namely the stratified proportional random sampling and the systematic random sampling for the respondents in each household who answered a set of questionnaires, while a purposive or deliberate sampling was employed to the three church pastors who answered a different set of questionnaires instead of asking the opinion of all the other church leaders. This is a sampling with a purpose.

Varied tools were employed in the study to gather the necessary data. A normative survey questionnaire of the Faith Communities Today (A Congregational Survey of Denominational Survey of Denomination/Group) from the Hartford Institute for Religious Research taken from internet source was mainly used in this study. Some questions used by Tuggy and Toliver (1972) was also integrated to gather data in retrospect of the Church in the Philippines. Moreover, the researcher also added her own questions to supplement and complete the questionnaire.

There were less statistical procedures employed because of the descriptive nature of the study. The Percentage and the Weighted Mean formulas were utilized for problem number 4 . They are the following:

$$
\mathrm{P}=\frac{F}{n} \times 100 \%
$$

where:

$$
\begin{aligned}
& P=\text { percentage } \\
& f=\text { frequency } \\
& n=\text { number of cases } \\
& 100=\text { constant }
\end{aligned}
$$

and

$$
\mathrm{W}=\frac{\sum f_{i} X_{i}}{n}
$$

where:

$$
\mathrm{W}=\text { the weighted mean }
$$




$$
\begin{gathered}
\mathrm{f}=\text { the frequency } \\
\mathrm{w}=\text { the weight } \\
\Sigma=\text { summation }
\end{gathered}
$$

\section{Results and Discussion}

This portion presents the historical beginnings, changes, practices, beliefs, values, and programsof the three churches.

\subsection{The Foursquare Church}

The church of the Foursquare Gospel in Cebu is presently standing along 115 Rahmann Street, Cebu City. It began its work in Cebu on March 1, 1957 in a rented place along 168 Gorordo Avenue by American missionary couples, Rev. and Mrs. A.B. Chaves.

In an interview made with Pastor Val Chaves, the researchers asked about the present mission/vision of the church that is also mentioned in the questionnaire that he answered in which stated that "Every member becoming spiritually strong, mature and fruitful serving God and people". However, church mission/vision at present has some slight differences from the past because, the old mission/vision mostly focused on the furtherance of the Gospel and the dissemination of the church existence to attract more member to join in repentance and baptism. Salvation of the people was given more emphasis and the saving of souls, although meeting the physical and social needs were also one of its important concerned but not so specifically emphasized. As the church expanded, transition period also followed and they started studying as how the members' needs would be met in the different areas like spiritual, moral, social and economic aspects.

The Church' beliefs in the Pentecostal churches have embodied spiritual beliefs fundamentally taken from the Holy Scriptures. This serves as the bases of their faith in God and all other teachings coming from His Word. Furthermore, the Church of the Foursquare Gospel of Cebu believed on the following: (a) there is one God, eternally existent in the three persons: God the Father, God the Son, and God the Holy Spirit; (b) Jesus Christ was born in a virgin birth, was resurrected from the dead, was ascended to the right hand of the father and the hope of the Bible is the inspired and infallible Word of God; (c) His future plans on earth is to receive to Himself, His blood bought church; (d) the only means of being cleansed from his sin is thru repentance and by accepting Jesus as your personal Savior and Lord; (e) in water baptism by immersion, and all who repent should be baptized in the name of the Father, and of the Son and of the Holy Spirit; (f) the redemptive work of Christ on the cross provides healing of the human body in answer to a believing prayer; $(\mathrm{g})$ the baptism with the Holy Spirit, according to Acts 2:4, is given to believers who ask for it, following the new birth; (h) there is a resurrection of both righteous and the wicked, the one to Everlasting life and the other to Everlasting Damnation; (i) baptized believer may receive one or more of the supernatural gifts known in the early church instantaneous sanctification, the ability to prophecy, to practice divine healing thru prayer, to speak in tongues, discernment of spirits, and emphasis on miracles, exorcism and deliverance; and (j) teaching of a 100\% tithes belong to God, is due for Him and should be given to Him.

However, the researchers were also able to gather the Cebu City Foursquare Gospel "Tenets 


\section{Macrothink}

of Faith" from the year 1959 publications, "GLEAM". These are their personal beliefs in church:

"We Believe"

In the verbal inspirations of the Scriptures.

In the absolute trinity of the eternal Godhead.

In the deity of our Lord Jesus Christ.

In the personality and deity of the Holy Ghost.

In the substitutionary atonement.

In full salvation by grace through faith and not of works.

In divine Healing through the atonement.

In the personal Baptism of the Holy Ghost

As received by the apostles.

In water baptism by immersion.

In the middle-of-the road policy in public worship.

Between extreme fanaticism and ultra-ritualism.

In obedience to civil government.

In tithing as God's financial plan.

In the open table at the Lord's Supper.

In a literal heaven and life everlasting for all true believers.

In the everlasting punishment of the impenitent.

In the personal, literal, bodily pre-millennial coming of Jesus Christ.

In a future, literal, 1,000 year reign of Christ on earth with all.

His saints. In the immortality and conscious existence of the soul.

In Christian tolerance to all denominations of the Christian faith.

In essentials-unity; in Non-essentials-liberty; in all things charity.

The tenets of Faith presented above was the original text written and published in 1959 as Cebu Foursquare Gospel's sound doctrines and teachings based from the Bible. It showed similar ideas from the beliefs commonly believed by Pentecostal believers. In the year 2004, the researchers were able to trace its historical changes which are apparent in the way they changed the sequences and the statements made for their "Tenets of Faith" supported more specifically from the Scriptures, but having the same overall idea in its sense:

"This We Believe"

The Holy Bible. We believe the Holy Bible is God-inspired. (1 Timothy 3:16-17)

The Eternal Godhead - We believe God is Triune - Father, Son and the Holy Spirit. (1 John $5: 7)$

The Fall Of Man - We believe that man was created in the image of God, but by voluntary disobedience he fell from perfection. (Romans 5:12)

The Plan of Redemption - We believe that while we were yet sinners Christ died for us, 


\section{Mll Macrothink}

signing the pardon for all who believed in Him. (John 3:16)

Salvation through Grace - We believe we have no righteousness and must come to God pleading the righteousness of Christ. (Ephesians 2:8)

Repentance and Acceptance - We believe that upon sincere repentance and whole hearted acceptance of Christ, we are justified before God. (1 John 1:9)

The New Birth - We believe that the change which takes place in the heart and life at conversion is a very real one. (John 3:3)

Daily Christian Life - We believe that it is the will of God that we will sanctified daily, growing constantly in faith. (Hebrews 6:1)

Baptism and the Lord's Supper - We believe that baptism is an outward work. We believe in commemoration of the Lord's supper by the symbolical use of the bread and the juice of the wine. (Matthew 28:19; 1 Corinthians 11:28)

Baptism of the Holy Spirit - We believe that the baptism of the Holy Spirit is to endue believer with power, and that his incoming is after the same manner as in the Bible days. (Acts 2:4)

The Spirit Filled Life - We believe that it is the will of God that we walk in the Spirit daily. (Galatians 5:16, 25)

The Gifts of the Holy Spirit - We believe that the Holy Spirit has gifts to bestow upon the Christians; and we should show spiritual fruit of a Spirit-filled life. (1 Corinthians 12:1-11; Galatians 5:22)

Moderation - We believe that the experience and the daily walk of the believer should never lead him into the extremes of fanaticism. (Philippians 4:5)

Divine Healing - We believe that divine healing is the power of Christ to heal the sick in answer to the prayer of faith. (James 5:14-16)

The Second Coming Of Christ - We believe that the second coming of Christ is personal and imminent. (1 Thessalonians 4:16-17)

Church relationships - We believe it is our sacred duty to identify with the visible Church of Christ. (Acts 16:5)

Civil Government - We believe that rulers should be upheld at all times except in the things opposed to the will of God. (Romans 13:1-5)

The Final Judgement - We believe that all shall stand before the judgement seat of God, and there receive eternal life or death. (11 Corinthians 5:10)

Heaven - We believe that heaven is the glorious eternal home of born-again believers.

Hell - We believe that hell is a place of eternal torment for all who reject Christ as their Savior. (Revelation 20:10-15)

Evangelism - We believe that soul winning is the one big business of the church on earth. (James 5:20)

Tithes and Offering - We believe that the method ordained of God for the support and spread of his cause is by giving of tithes and free-will offerings. (Malachi 3:10-11; 11 Corinthians 9:7) 
These are the modified and clearly presented beliefs with supporting verses from the Bible which the Church of the Foursquare Gospel members adhere to at present. But though the statements and phrases differ, the same concepts and ideas are conveyed by each tenets of faith presented. Additionally, the Church practices had their customary ways and distinctive activities that made them different with the other religious groups. In the Questionnaire, all the items were answered YES, as practiced by the church without giving additional answers as another form of practice in the congregation. The following are the Church of the Foursquare Gospel of Cebu practice: (a) praying with upraised hands; (b) musical instruments as part of worship; (c) clapping and dancing before the Lord in worship (Psalm 47:1; Psalm 150:4); (d) laying of hands (to the sick or anyone who need prayer); (e) partaking of the Lord's supper; (f) adults baptism (12 years-up); (g) lively welcome of visitors in the congregations (thru musical instrument); (h) kneeling (or prostration) by the congregation; (i) a time for (lay persons) to testify about their faith; (j) a time for people to greet each other (or pass the peace); (k) use of visual projection equipment; and (l) invitation of guest speakers from other congregation to preach.

The Church of the Foursquare Gospel - Cebu has several core values which are considered very important personal decisions and commitments to be followed by every member of the congregation: (a) Evangelistic priority; (b) Christ exalting; (c) Our Message: Christ the Savior, Baptizer, Healer and the Coming King; (d) Our Theme verse: Hebrew 13:8, Jesus Christ is the same, yesterday, today and forever"; (e) Christ Claim: "If I am lifted up above the earth, I will draw all men to me" John 12:32; (f) The Human cry: "... we would see Jesus" John 12:21; (g) Our call to proclaim Christ to the world; (h) Spirit-filled Churches; (i) Preaching/teaching the baptism with the Spirit - an Acts 2 experience; (j) Encouraging people to experience and live a Spirit-filled life; (k) Contending for supernatural; (1) Healings, deliverance, empowering men and women, young and old, relevantly practicing the gifts of the Holy Spirit, The cutting edge of Ministry; (m) Balance in Doctrine and Conduct; (n) World Mission Passion; (p) Prophetic Teaching and Preaching;(q) Edification, Exhortation, Encouragement, Interdenominational in Spirit; (r) Inclusive of Cultures, Genders and Generations; (s) Churches that Reproduce Ministers and Ministries; (t) Value a Church Environment of Life, Joy and Hope; (u) Providing Places to Serve; (v) Team Perspective; (x) Reliability, Purpose, Worth, Confidence, Accomplishment, Belonging, a Fresh Vision; and (w) an understanding of our collective potential, a revelation of our divinely given destiny, an enlargement of our corporate vision, and an embracing of our vision.

In other words, their core values are inclined most to the idea of sharing the Gospel through evangelization and world missions. But each member and believer of Christ are encouraged to be fully equipped with God's Word and spiritual gifts to be able to fit in to the different ministries where they can best serve God.

The congregational programs are catered by the different ministries in their church. These programs are set to determine what various activities can be accomplished in either short term or long term basis to pursue the mission and vision of the church: (a) Bible study on going during a season; (b) Theological or doctrinal Study on-going thru (church); (c) Sunday School for kids on-going thru (church); (d) Spiritual retreats on one-time, short term occasion; 
(e) Prayer or meditation groups on-going thru (church); (f) Parenting or marriage enrichment on-going during a season; (g) Performing arts like music, dance and drama on-going thru (church); (h) Groups that discuss books or contemporary issues on-going during a season; (i) Self-help or personal growth groups on-going thru (church); and (j) Sports teams on one time or short term occasion.

Specifically, these were the different programs provided by the Cebu City Foursquare Gospel in the past twelve months catering the different needs of the members in the area of spiritual, moral and social aspects. The items that were answered YES or evangelistic campaign programs are the following: Growth or evangelistic campaign programs; Focused efforts to identify the contact people who have recently move into your congregation area; Stressing in your congregation's preaching and teaching the importance of 'witnessing' to others about one's faith; Special worship services intended to attract (the un-churched/non-members) like: 'Bring a Friend' service, Seeker services, Revival meetings, Christian concerts; Special programs especially intended to attract (un-churched/non-member) in your community, like: Parenting classes, Young single nights, Phone calls or personal visits by (clergy), and phone calls or personal visits by (laity).

However, there were some programs that were not provided by the congregation in the past twelve months. These were the items answered with NO, by the members of the church like: Newspaper advertisement and stories; radio or television advertisement or stories; direct mail promotions to area residents; art festivals to attract un-church or non-members in their community; street ministries to attract un-church or non-members in their community.

There were also activities like: cash assistance to families or individuals which was provided directly by their congregation; counselling services or "hotline"; school programs like student center cooperated with another congregation, agency or organization; and employment counselling, placement or training education particularly the recruitment cooperated with another congregation, agency or organization.

It proved that the Church of the Foursquare Gospel provided several programs that catered the member's needs in the economic aspect although there were several programs that were not provided in the past twelve months. The following programs presented below are the items that were answered NO by the members of the Foursquare Gospel. These are: food pantry or soup kitchen; thrift store or thrift store donation; elderly, emergency or affordable housing; senior citizen programs; and prison or jail ministry. Although these programs were not provided by the congregation, the members of the Foursquare Gospel are willing to support these activities if implemented in the church.

There are some historical features needed to be emulated, revived and modified. In an oral interview to Rev. Val Chaves of the Cebu City Foursquare Church, the given questions emphasized more on important transitions in terms of its mission and vision, beliefs and practices, Christian values taught and the congregational programs. He said that the church mission and vision during its beginnings was more emphasized on reaching people for Christ to obtain salvation and eternal life. The practices in the church were very conservative and had solemn services. Ladies were taught proper dress code like wearing Sunday dresses on Sundays instead of wearing jeans. Altar calls were made after the service or at any time of the service when there was a need to pray for healing, salvation or any petitions of the believer. 
But at present, the church had broken away from its conventions especially in terms of worshipping God in a solemn manner. They used to have choir in the past that are now replaced by the Praise and Worship team when they played more loud and lively music. In terms of values infallibility of the Bible, not compromising with the Word, and salvation that comes from Christ alone is very evident. Holiness was also emphasized to speak the right relationship with the Lord. Evangelism is very important because without the preaching of the Gospel. He cited some congregational programs that have changed from the past and those that were improved. He said that they depend most on the move of the Holy Spirit when they do not really follow a standard program of activities. More so, they also used to pray before the start of our service which they do not practice now and thus this needs to be revived.

\subsection{Faith Tabernacle}

The Faith Tabernacle started in Cebu City on the ending week or November 1972 under the leadership of Rev. Ben Tagud. It was laid in an old building at the corner of Simoun and D. Jakosalem Street, Cebu City. It was here that the seed of Faith Tabernacle movement was established and flourished. The secret of the progressive development was the extensive command of evangelism and prevailing prayer. Five years later, the Faith Tabernacle fellowship has transferred to a wider space in Cuenco Building at corner D. Jakosalem and Sanciangko Streets.

The historical changes of Faith Tabernacle are based on the mission and vision of the church. Itis believed that "To build up the body of Christ and to reach the world by the Gospel as commanded". The Faith Tabernacle mission/vision never changed since its founding but is gradually making its way to its full implementation at present with the establishment of varied church ministries like the training of pastors in their Bible School to reach the world in sharing the Gospel of Jesus Christ and to plant more local churches.

Like the Foursquare Gospel Church, the Faith Tabernacle also embodied similar spiritual beliefs fundamentally taken from the Holy Scriptures. Here are the following beliefs answered by YES on each item and the option to add more if it is not found in the items provided. The Faith Tabernacle Church believed on the following: (a) there is one God, eternally existence in the three person: God the Father, God the Son and God the Holy Spirit; (b) Jesus Christ was born in a virgin birth, was resurrected from the dead, was ascended to the right hand of the father and the hope of The Bible is the inspired and infallible Word of God; (c) His future on this earth is to receive to Himself His blood bought church; (d) the only means of being cleansed from his sin is through repentance and by accepting Jesus as your personal Savior and Lord; (e) in water baptism by immersion, and all who repent should baptized in the name of the Father, and of the Son and of the Holy Spirit; (f) the redemptive work of Christ on the cross provide healing of the human body in answer to believing prayer; (g) the baptism with the Holy Spirit, according to Acts2:4, is given to believers who ask for it, following the new birth. There is a resurrection of both righteous and the wicked the one to Everlasting life and the other to Everlasting Damnation; (h) baptized believer may receive one or more of the supernatural gifts known in the early church: instantaneous sanctification, the ability the prophesy, to practice divine healing through prayer, to speak in tongues, discernment of spirits, emphases on miracles, exorcism and deliverance; and (i) teaching that 
a $10 \%$ tithe belong to God, is due God and should be given to God;

The Faith Tabernacle has also similar customary ways and distinctive activities with other Pentecostal churches. In the Questionnaire, all the items were answered YES, as practiced by the church and have given additional answers as another form of practice in the congregation. The following are the Faith Tabernacle Church practices: (a) praying with upraised hands; (b) musical instruments as part of worship; (c) clapping and dancing before the Lord in worship; (d) laying of hands (to the sick or anyone who need prayer); (e) partaking of the Lord's supper; (f) adults baptism (12 years-up); (g) lively of welcoming visitors in the congregation (through musical instrument); (h) kneeling (or prostration) by the congregation; (i) a time for (lay persons) to testify about her faith; (j) a time for people to greet each other (or pass the peace); (k) the use of visual projection equipment; (l) invitation of guest speakers from other congregation to preach; and $(\mathrm{m})$ other practices are: Christmas celebration and Holy Week celebration.

The most important emphasis of the Faith Tabernacle in terms of its Christian values taught in their church is the message of the Gospel where salvation through Jesus Christ held most significant for every believer to hold. Believers' in the church are also encouraged to be Christ-like, emulating His unselfish love, kindness and compassion to mankind. Honesty, generosity, fear of the Lord, integrity, faith and boldness in sharing the Gospel are also taught as important values to follow.

The Faith Tabernacle' Existing Congregational Programs are during the past twelve months, the congregation have the following programs: (a) studies on going occasionally, during a season and on-going thru church; (b) theological or doctrinal study on going during a season; (c) Sunday school for adults and kids on going during a season; (d) spiritual retreats on one-time, short term occasion; (e) prayer or meditation groups on one time, short term occasion; (f) parenting or marriage enrichment on going thru (church); (g) performing arts like music, dance and drama on going during a season; (h) groups that discuss books or contemporary issues on one time, short term occasion; (i) self-help or personal growth groups on going during a season; $(\mathrm{j})$ youth/teen activities and programs on one time, short term occasion; and (k) bible Young adults/singles activities and programs on one time, short term occasion.

In addition, the Questionnaire asked about other programs or activities done during the past 12 months to reach out to new or inactive participants or to make the congregation better known in the community. The items that were answered NO and have not done in the last 12 months but members would support these activities were the following: (a) newspaper advertisements and stories; (b) radio or television advertisements or stories; (c) direct mail promotions to area residents; (d) growth or evangelistic campaign program; (e) focused effort to identify and contact people who have recently move into your congregation area; (f) stressing in your congregation's preaching and teaching the importance of 'witnessing' to others about one's faith; (g) special worship services intended to attract (the unchurched/non-members) like: Bring a friend services, Seeker services, Revival meetings, and Christian concerts. Special programs especially intended to attract (unchurch persons/non-members) in your community like: Parenting classes; Young single nights; Art festivals; Street ministries; Phone calls or personal visits by your (clergy leaders); and Phone 
calls or personal visits by (laity).

Finally, the Questionnaire also asked about the congregational programs that directly provide, or cooperate in providing services to their own members or for the people in the community which include financial contributions, volunteer time by congregational members space in your building, material donations and many others done in the past 12 months. The following items that were Yes (provided directly by your congregation) are the following: Food pantry or soup kitchen; Cash assistance to families or individuals; Counselling services or 'hotline'; Day care, pre-school, before/after school programs; and Employment counselling, placement or training education. The following items were answered NO were the following: Elderly, emergency or affordable housing; Thrift store or thrift store donations; Senior citizen programs (other housing); and Prison or jail ministry.

One important church practice in Faith Tabernacle is the altar call when members who have some prayer needs come in front to be prayed for by the minister. More so, the very important congregational programs in Faith Tabernacle are leading crusades primarily intended to reach out people in neighboring places who have not known Christ yet. The Faith Tabernacle also provided a feeding program to selected slum areas in Cebu City which mostly catered children.

There are some historical features needed to be emulated, revived and modified. In an oral interview made by the researcher to Rev. Venancio "Ben" Tagud, of the Faith Tabernacle, the given questions were emphasized more on important transitions in terms of its mission and vision, beliefs and practices, Christian values taught and the congregational programs. The purpose was to find out if there were some significant changes and developments happening from the beginning of its establishment up to the present and the actions that were taken to emulate, revive or modify any particular church programs and teachings. He mentioned about some changes in their mission and vision that are now fully implemented. In terms of church practices, the major change in our church practices from the past to the present is then changing from solemn worship to live prayers and the old songs to the new Praise and Worship songs. However, maintaining altar calls during and after the worship service or preaching to cater the needs of the people like prayer for salvation, healing, deliverance, or dedication are still practiced. In terms of church values, he emphasized the teachings of the Gospel, the saving of souls, and the edifying of the church to be spiritually strong in the Lord. He also enumerated implemented programs and activities since 1980s to the present that will help people at the same time evangelize the message of God.

\subsection{Immanuel Fellowship}

Immanuel Fellowship started with a group of men and women who were part of a Roman Catholic renewal movement that invited every Tuesday a Pentecostal Bible Study teacher by the name of Rev. Narciso Dionson. Eventually a group of people saw the need to experience the Lord Jesus Christ not because of religious tradition but through Biblical foundation. This group of people stood in behalf of the truth and came out of the mainstream and followed the conviction of the Holy Spirit.

It is interesting to note that Rev. Narciso Dionson has a heart for church planting. He founded a Pentecostal church named Trinity Christian Center in the 70s in and with its split it formed 
another church called Messiah Christian Assembly which is now under different ministers at present. All these churches he planted however were under a huge religious organization called Assemblies of God, the oldest and largest Pentecostal denomination in the Philippines since the 1920s which was formed early by American missionaries. The Assemblies of God in Cebu City was started most remarkably by Jay Edward Blount in 1955 under a local church called Cebu Revival Center.

In 1995, Immanuel Fellowship formulated its mission which says "Immanuel Fellowship exist to mobilize a caring family of believers who love God with their whole being and empowered by the Holy Spirit in order to fulfil the Mission of Jesus Christ which is to seek and save the lost."In 1996 the Lord gave Immanuel Fellowship its vision which says "By God's grace, we want to be a church which would establish an integrated and effective ministries of worship, discipleship, fellowship, evangelism and service which will encompass Metro Cebu."

True to its vision, the church today has about 26 cell groups in just two years which served as an avenue of integrated ministries of worship, discipleship, fellowship, evangelism and service. These are being pastored by their zone pastors and supervisors. Their next vision is to plant 15 effective cell churches in the Visayas region which presently was carried out with 12 churches planted and is still aiming for planting three more churches to complete their right target.

Recently, the mission statement of Immanuel Fellowship is: "We are a caring family of God-fearing Christians who are equipped and empowered by the Holy Spirit to bring healing and hope in this broken world. 'It is followed by their vision statement which says "To become a mature and growing church, aggressively bringing the Gospel of Christ to the communities, cities and the nations beyond."

The Church Beliefs, like any other Pentecostal Churches, Immanuel Fellowship also embraced fundamental beliefs grounded from the Bible which served as sound doctrines in the faith they professed. The Immanuel Fellowship believed on the following: (a) there is one God, eternally existent in the three persons: God the Father, God the Son and God the Holy Spirit; (b) Jesus Christ was born in a virgin birth, was resurrected from the dead, was ascended to the right hand of the father and the hope of The Bible is the inspired and infallible Word of God; (c) His future to this earth to receive to Himself His blood bought church; (d) the only means of being cleansed from his sin is through repentance and by accepting Jesus as your personal Savior and Lord; (e) in water baptism by immersion, and all who repent should be baptized in the name of the Father, and of the Son and of the Holy Spirit; (f) the redemptive work of Christ on the cross provide healing of the human body in answer to believing prayer ( $\mathrm{g}$ ) the baptism with the Holy Spirit, according to Acts 2:4, is given to believers who ask for it, following the new birth; (h) there is a resurrection of both righteous and the wicked, the one to Everlasting life and the other to Everlasting Damnation; (i) a baptized believer may receive one or more of the supernatural gifts known in the early church instantaneous sanctification, the ability the prophesy, to practice divine healing through prayer, to speak in tongues, discernment of spirits, emphasis on miracles, exorcism and deliverances; and (j) teaching that a $10 \%$ tithe belong to God, is due God and should be given to God. 


\section{Macrothink}

The Immanuel Fellowship has also its "Tenets of Faith" in addition to the church practices in which this was taken from their amended By-Laws in 2003, under Article II - Tenets of Faith.

\section{"Tenets of Faith}

1. The Scriptures Inspired

2. The One True God

3. The Deity of the Lord Jesus Christ

4. The Fall of Man

5. The Salvation of Man

a. Condition to Salvation

b. The Evidence of Salvation

6. The Ordinances of the Church

a. Baptism in Water

b. Holy Communion

7. The Baptism in the Holy Spirit

8. The Evidence of the Baptism of the Holy Ghost

9. Sanctification

10. The Church and its Mission

\section{The Ministry}

12. Divine Healing

13. The Blessed Hope

\section{The Millennial Reign of Christ}

\section{The Final Judgement}

The Church practices distinguish one denomination from the other Immanuel Fellowship shared similar practices with the other two pioneering Pentecostal churches which proved their commonality. The following are the Faith Tabernacle Church practices: (a) praying with upraised hands; (b) musical instruments as part of worship; (c) clapping and dancing before the Lord in worship; (d) laying of hands (to the sick or anyone who need prayer); (e) partaking of the Lord's supper; (f) adults baptism (12 years up); (g) lively welcoming of visitors in the congregation (through musical instrument); (h) a time for (lay persons) to testify about their faith; (i) a time for people to greet each other (or pass the peace); (j) the use of visual projection equipment; $(\mathrm{k})$ invitation of guest speakers from other congregation to preach; and (1) other practices are: Christmas celebration and Holy Week celebration. Only kneeling or prostration was not practiced in Immanuel Fellowship.

The Immanuel Fellowship program assimilates new members in the family of believers called The Foundations of Life. This is where they are welcomed through a party to be done once a month. To grow in their spiritual walk, they undergo a process where they would be equipped with God's Word to maturity which they call, the 4Ms namely: maturity, mission, ministry and membership.

In an interview with Pastor Narciso Dionson, he mentioned the value of worship, which 


\section{$\triangle$ Macrothink}

means teaching an individual to get closer to God through praising and worshipping His name which is an intimate act of faith. Another is a value of fellowship where fellow believers are encouraged to gather together in God's house in fellowship with one another for the edification of the church. Seeking God's leading for the right ministry is another value taught to encourage every believer to serve the Lord according to his gifts and talents. This means their dynamic expression to serve the people of God through their time, talents and spiritual gifts in response to God's faithfulness. This is the process of bringing the Gospel to a different group of people which involves crossing varying cultural distances. Finally, the membership is the process of attracting and assimilating attendees into the caring family of their congregation.

In an interview with the head pastor of Immanuel Fellowship, several congregational programs were identified to be in effect in the past months: (a) Bible studies on going occasionally, during a season and on-going thru church; (b) theological or doctrinal study on-going during a season; (c) Sunday school for adults and kids on-going thru (church);Spiritual retreats on-going during a season; (d) Prayer or meditation groups on-going during a season; (e) Parenting or marriage enrichment on-going during a season; (f) Performing arts like music, dance and drama on-going during a season; (g) Groups that discuss books or contemporary issues on-going during a season; (h) Self-help or personal growth groups on-going during a season; (i) Sports teams on-going thru (church); (j) Youth/Teen activities and programs on-going during a season; and (k)Young adults/singles activities and programs on-going thru (church).

In addition to the programs mentioned above, the Questionnaire asked about other programs or activities done during the past 12 months to reach out to new or inactive participants or to make the congregation better known in the community. The items were answered YES and have done in the last 12 months were the following: Newspaper advertisements and stories; Growth or evangelistic campaign program: Focused efforts to identify and contact people who have recently move into your congregation area; Stressing in your congregation's preaching and teaching the importance of 'witnessing' to others about one's faith; Special worship services intended to attract (the unchurched/non-members) like: 'Bring a friend' services, Seeker services, Revival meetings, Christian concerts; Special programs especially intended to attract (unchurched persons/non-members) in your community like: Young single nights.

The programs or activities that were answered NO in the last 12 months but (Members) would probably support these activities if implemented were the following: Radio or television advertisements or stories; Direct mail promotions to area residents; Special programs especially intended to attract (unchurched/non-members) in your community like: Parenting classes, Art festivals, Street ministries, Phone calls or personal visits by your (clergy leaders), Phone calls or personal visits by your (laity).

Finally, the Questionnaire also asked about the congregational programs that directly provide or cooperate in providing services to their own members or for the people in the community who include financial contributions, volunteer time by congregational members, and space in your building, material donations and many others done in the past 12 months: food pantry or soup kitchen, cash assistance to families or individuals, and thrift store or thrift store 
donations. The following items that were answered NO were the following: elderly, emergency or affordable housing, counselling services or 'hotline', daycare, pre-school, before or after school programs, employment counselling, placement or training education, senior citizen programs (other housing), and prison or jail ministry

Immanuel Fellowship additionally has an annual program for children called, "Kid's Camp" which has the same concept as a daily vacation Bible School during summer. Kids enjoyed different activities like Bible stories, skits and games. They are awarded certificates at the end of the 5 to 7 days activities.

In an oral interview made by the researcher to Rev. Narciso Dionson, the questions were emphasized more on important transitions in terms of its mission and vision, beliefs and practices, Christian values taught and the congregational programs. The purpose was to find out if there were some significant changes and developments happening from the beginning of its establishment up to the present and the actions that were taken to emulate, revive or modify any particular church programs and teachings. He said that there had several mission and vision statements modified since the last decade but last 2003. They simplified them again following the principle on the Purpose Driven Life by Rick Warren. It was a 6-week campaign from the month of December to the middle of February where we successfully brought 27 converts to Christ.

He also shared some of their church practices at present that are not similar to the past, saying they cut out the altar calls for various prayer needs because of time constraint since they need to move out before the theatre will open for movie viewing at Cinema 4, Ayala Center Cebu. He emphasized several important Christian values he taught in church and pointed out some similar values from the past that are still observed until the present that is to teach and emulate the value of worship, which means learning how to press on and flow with the Spirit realm in communing with God. He cited some congregational programs that have changed from the past and those that were improved.

\section{Conclusion}

The three pioneering Pentecostal churches involved in this study had different historical beginnings under different leaders. Their growth and development had experienced an upward trend from their humble beginning until the present. These can be attributed much to their congregational programs which strengthened their own church ministries. These three Pentecostal churches are religious corporations independent from one another, having legal and ecclesiastical bylaws which implement laws, regulations, discipline and teachings in their own congregations.

They all have the same practices but have some slight differences on the basis of their own style and characteristics of people and leaders, venue of their services and the congregational programs implemented. Their Christian values taught are similar following the teachings from the Bible like Christian love, faith and hope in God, the sharing of the Gospel to everyone and living a Christ-like example to people. 


\section{Macrothink}

Journal of Asian Development

ISSN 2377-9594 2017, Vol. 3, No. 2

\section{References}

Adams, L., \& Tryggestad, E. (2002). A Conversation With Tim Martin: The Christian Chronicle. Retrieved from http://www.Christianity.com/partner/articledisplaypage/0..PTID25485\% $7 \mathrm{cc}$.

Alabang New Life Christian Center. (1994). Church History and their Tenets of Faith. Pamphlet, 1994

Aparece, U. B. (2003). Sukdan Curing Practices in Anonang, Bohol: An Ethnography of Performance. Unpublished Dissertation, University of San Carlos, Cebu City, Philippines.

Author Unknown. History of Elim. Retrieved from http://www.wlimcs.org/Home\&News/history.html-12k.

Author Unknown. The Pentecostal Assemblies of Canada (2002). Retrieved from http://www.paoc.org/pdf/gc2002-minutes-v3pdf.

Bishop, M. (2002). The Church as Subversive Community. Retrieved from http://www.christianitytoday.com/pastors/2007/july-online-only/020610.html.

Blackett, M. (2000). Church History of Pentecostalism. Retrieved from http://www.melncoly.com/contents.Html-1k.

Bayon, A. M. (1997). Chardin's Theory of Human Evolution Vis-à-vis Biblical Creation. Unpublished Master Thesis, Cebu Normal University, Cebu City, Philippines.

Blumhofer, E. L. (1989). Pentecost In My Soul. Springfield, Missouri: Gospel Publishing House, 1989.

Burgess, S. M., Mcgee, G. B., \& Alexander, P. H. (1988). Dictionary of Pentecostal and Charismatic Movements. Grand Rapid, Michigan: Zodervan Publishing House.

Cadwell, C. (2014). The Assemblies of God and the Worldwide Growth of Pentecostalism. American Denominations and other Religious Movements. Southwestern Baptist Theological Seminary. Fort Worth, Texas.

Cebu City Foursquare Gospel. (1993). Articles of Incorporation and ByLaws.

Cortez, M. (2014). The growth of global Pentecostalism. (Wheaton Theology Conference 4). Retrieved from http://marccortez.com/2014/04/16/growth-global-pentecostalism-wheatontheology-conference-4/.

Faith Communities Today. A Congregational Survey of Denomination/Group. Retrieved from http://www.uua.org/cde/education/fctsurveyresults.pdf

Faith Tabernacle. (1993). Articles of Incorporation and ByLaws.

Faith Tabernacle. History Manuscript. (Undated)

Hamilton, Adam J. (2000). Living Evangelism: Lessons for Churches from Kansas City's Eateries. Retrieved from http://www.cor_org/devsite/home/ftv/adamwelcome.htm-12k 
Immanuel Fellowship. (2000). Mission/Vision Statement, 2002. We Shall Overcome.

Immanuel Fellowship. (1993). Articles of Incorporation and Amended ByLaws.

Immanuel Fellowship. History, Manuscript. (Undated)

Interview with Rev. Val Chaves - Senior Pastor of Cebu City Foursquare Gospel, 2004

Interview with Rev. Narciso Dionson - Pulpit Minister and founder of Immanuel Fellowship, 2004

Interview with Rev. Rejulson Lagunero - District Supervisor of Cebu City Foursquare Gospel, 2004

Interview with Rev. Pedro Quiliope - Divisional Superintendent of Cebu City Foursquare Gospel, 2004

Interview with Rev. Ben Tagud - Senior Pastor of Faith Tabernacle, 2004.

Kuiper, B. K. (1951). The Church in History. Grand Rapids, Michigan: The National Union of the Christian Schools.

Labajo, D. R. (2000). A Historical Survey of Reformative and Dissident Religious Movements in Cebu: 1990-2000. Unpublished Master Thesis, University of San Carlos, Cebu City, Philippines.

MacGavran, D. A., Calcin, G. R., Hodge, M. L., \& Nida, E. A. (1965). Church Growth and Christian Mission. New York, Evanston and London: Harper and Row, Publishers.

Magsakay, V. T. (2003). Voter's Preferences Across Diversified Demographic Groups. Unpublished Master Thesis, Cebu Normal University, Cebu City, Philippines.

Moyer, S. E. (1951). Great Leaders, Volume 1 and 2. Chicago 10, Illinois: Moody Bible Institute of Chicago.

Nermal, A. T. (1986). The growth and the Development of the Seventh Day Adventist Church in Northern Mindanao, 1937-1983. Unpublished Master Thesis, University of San Carlos, Cebu City, Philippines.

Panopio, I. et.al. (1995). General Sociology: Focus on the Philippines. Ken Publishing. Quezon City, Philippines.

Pradhan, H. (1994). The Protestant Chinese and their Contribution to the Socio-Economic and Cultural Development of Cebu City, 1916-1988. Unpublished Master Thesis, University of San Carlos, Cebu City, Philippines.

Quiliope, P. B. (2002). The Sovereign Act of God: The Church Building on Fire But Not Burned. Cebu City Foursquare Gospel, Unpublished Journal.

Rogers, A. (2016). Being Built Together project. Religion and the Public Sphere. The London School of Economics and Political Science. Retrieved from http://blogs.lse.ac.uk/religionpublicsphere/about/. 


\section{Macrothink}

Journal of Asian Development

ISSN 2377-9594 2017, Vol. 3, No. 2

Schaefer, R. T., \& Lamm, R. P. (1997). Sociology: A Brief Introduction. Printed in the United States of America. McGraw-Hill Publishing Company.

Sevilla, C., et.al. (1992). Research Methods. 84 P. Florentino St., Quezon City: Rex Printing Company, Incorporated.

Sharma, K. B. (2001). A History of the Pentecostal Movement in Nepal. Asian Journal of the Pentecostal Studies. Retrieved from http://www.apts.edu/ajps/0-1-1/b-sharma.pdf.

Siewert, F. (1987). The Amplified Bible. La Habra, California: Zondervan Publishing House.

Tuggy, L. A., \& Ralph, T. (1972). Seeing the Church in the Philippines. Marquez de Comillas, Paco Manila: O.M.F. Publishers, 1.

Varela, C. B. (1959). A History of Biblical Christianity in Cebu: Centennial Celebration of Biblical Christianity, 1998. Philippine Council of Evangelical Churches; Unpublished Journal, 1998. Cebu City Foursquare Gospel. We Believe. Cebu Bible Institute, Gleam.

\section{Copyright Disclaimer}

Copyright for this article is retained by the author(s), with first publication rights granted to the journal.

This is an open-access article distributed under the terms and conditions of the Creative Commons Attribution license (http://creativecommons.org/licenses/by/4.0/). 